\title{
Urgensi Pendidikan Seksual dalam Pembelajaran bagi Siswa MI/SD untuk Mengatasi Penyimpangan Seksual
}

\author{
Rosdiana Dewi ${ }^{1}$, Nurhasanah Bakhtiar ${ }^{2}$ \\ ${ }^{1}$ Mahasiswa Magister Pendidikan Guru Madrasah Ibtidaiyyah, Universitas Islam Negeri Sultan Syarif \\ Kasim Riau, Indonesia \\ ${ }^{2}$ Dosen Magister Pendidikan Guru Madrasah Ibtidaiyyah, Universitas Islam Negeri Sultan Syarif \\ Kasim Riau, Indonesia
}

\begin{tabular}{l}
\hline \hline \multicolumn{1}{c}{ INFO ARTIKEL } \\
\hline Riwayat Artikel: \\
Diterima: $16-12-2020$ \\
Disetujui: $29-12-2020$ \\
Diterbitkan: $29-12-2020$
\end{tabular}

\section{Kata kunci:}

Pendidikan

Pembelajaran

Seks

LGBT

\footnotetext{
Alamat Korespondensi:

Rosdiana Dewi,

S2 Pendidikan Guru Madrasah Ibtidaiyyah

Universitas Negeri Islam Sultan Syarif Kasim Riau

E-mail: rosdianadewi694@gmail.com
}

Abstract: In general, people assume that sex education only contains the provision of genital information and various positions in sex. This will certainly make parents feel worried. For this reason, it is necessary to realign understanding of sex education. Sex education seeks to put sex in the right perspective and change negative assumptions about sex. The writing of this article contains a literature review on sex education for elementary students as well as handling the latest issues (LGBT, Sexual Violence) and implementing learning. The method of searching both international and national literature is done by using relevant journals and articles related to this research. Descriptive analysis is expected to obtain comprehensive and in-depth data. The steps taken include collecting library data, reading and recording, and comparing literature to then be processed and produce conclusions. The data used are secondary data from textbooks, journals, scientific articles, literature reviews that contain the concepts studied. The purpose of this study was to determine the importance of sexual education for MI / elementary students and their implications in learning.

\begin{abstract}
Abstrak: Pada umumnya orang menganggap bahwa pendidikan seks hanya berisi tentang pemberian informasi alat kelamin dan berbagai macam posisi dalam berhubungan kelamin. Hal ini tentunya akan membuat para orangtua merasa khawatir. Untuk itu perlu diluruskan kembali pengertian tentang pendidikan seks. pendidikan seks berusaha menempatkan seks pada perspektif yang tepat dan mengubah anggapan negatif tentang seks. Penulisan artikel ini berisi tentang kajian literatur tentang pendidikan seks bagi siswa SD Serta penanganan tetntang isu isu terbaru (LGBT, Kekerasan Seksual) serta mengimplemtasikan dalam pembelajaran. Metode sebuah pencarian literatur baik internasional maupun nasional yang dilakukan dengan menggunakan jurna- jurnal terkait serta artikel artikel yang berkaitan dengan penelitian ini. Dengan analisis deskriptif diharapkan dapat memperoleh data yang komprehensif dan mendalam. Langkahlangkah yang dilakukan diantaranya pengumpulan data pustaka, membaca dan mencatat, serta membandingkan literatur untuk kemudian diolah dan menghasilkan kesimpulan. Data yang digunakan merupakan data sekunder yang berasal dari textbook, jurnal, artikel ilmiah, literature review yang berisikan tentang konsep yang diteliti. Tujuan dari penelitian ini adalah untuk mengetahui pentingnya pendidikan Seksual bagi siswa MI/SD dan Implikasi dalam Pembelajaran
\end{abstract}




\section{LATAR BELAKANG}

Fenomena kekerasan dan penyimpangan seksual yang menimpa anak di bawah umur menjadi fokus perhatian pemerintah. Sejak masa pemerintahan Presiden Soesilo Bambang Yudhoyono, melalui Instruksi Presiden No. 5 Tahun 2014 tentang Gerakan Nasional Anti Kekerasan Terhadap Anak, permasalahan tersebut telah mencuri perhatian pemerintah karena tidak sedikit anak yang menjadi korban kekerasan dan penyimpangan seksual. Menurut data yang dihimpun dari kpai.go.id pelaku kekerasan terhadap anak meningkat setiap tahunnya. Hasil pemantauan KPAI dari 2011 sampai 2014, terjadi peningkatan yang sigfnifikan. Tahun 2011 terjadi 2178 kasus kekerasan, 2012 ada 3512 kasus, 2013 ada 4311 kasus, 2014 ada 5066 kasus (kpai.go.id).

Fenomena kekerasan dan penyimpangan seksual yang menimpa anak-anak di lingkungan mereka sendiri disebabkan oleh beberapa faktor, salah satunya adalah kurangnya pendidikan seks pada anak dan masyarakat. Menurut Yuliana (2016), seorang pemerhati perempuan dan anak dari Komunitas Jejer Wadon Solo, menyatakan bahwa maraknya kasus kekerasan seksual terhadap perempuan dan anak dipicu karena masih rendahnya pemahaman sex education atau pendidikan seks (http://solo.tribunnews.com/). Masyarakat, terutama orang tua, menganggap bahwa pendidikan seks merupakan sesuatu yang tabu dan tidak layak untuk diberikan kepada anak-anak mereka. Hal ini sejalan dengan pendapat Musdah (2016), Ketua Umum Indonesian Conference on Religion and Peace (ICRP), menyatakan bahwa Pendidikan seksual yang komprehensif adalah untuk mengajarkan menghargai dan mengapresiasi sesama manusia (http://nasional.kompas.com/).

Pendapat beberapa orang tua yang menganggap bahwa pendidikan seks untuk anak-anak adalah tabu, ternyata keliru. Pendidikan seks tidaklah sesempit yang diekspektasikan kebanyakan masyarakat, pendidikan seks sangatlah luas. Pendidikan seks erat kaitannya dengan cara mendidik anak di rumah maupun di sekolah. Menurut Suwaid (2010: 548) ada beberapa cara mengarahkan kecenderungan seksual anak, diantaranya: 1) melatih anak meminta izin ketika masuk rumah atau kamar orang tua; 2) membiasakan anak menundukkan pandangan dan menutup aurat; 3) memisahkan tempat tidur anak; 4) melatih mandi wajib; 5) menjelaskan perbedaan jenis kelamin dan bahaya berzina.

Pada kasus kekerasan seksual pada anak harus dilakukan pemeriksaan forensik karena merupakan syarat utama untuk proses penyelidikan di kepolisian, seperti yang diungkapkan dibawah ini : Kepolisian A mengatakan : "proses penyelidikan dapat dilakukan apabila didapatkan hasil pemeriksaan forensik menyatakan positif telah terjadi kekerasan seksual, sebagai data utama dalam pengajuan kepengadilan". Tenaga Forensik mengatakan: "hasil visum sangat penting dalam pemprosesan suatu kasus, karena hasil visum merupakan bukti otentik dari kebenaran suatu kasus yang terjadi". Selajutnya Hasil FGD adalah "Penyuluhan di daerah rawan terjadinya kekerasan seksual pada anak seperti di sekolah, pengajian dan lingkungan masyarakat tentang tanda gelaja, dampak psikologis dan penanganannya. Membangun hubungan yang berkualitas antara orangtua dan anak, Program Selamatkan dan Lindungi Anak dari Kekerasan Seksual (SELARAS) (Pendidikan Seksual berbasis Komunitas). Sistem Perlindungan Anak Terintegrasi. Membangun Kota Layak Anak (KLA)”.

Modul yang akan dikembangkan dapat digunakan oleh guru maupun orang tua sebagai pedoman dalam mendidik anak mengenai pendidikan seks. Selain sebagai pedoman pendidikan seks untuk anak usia MI/SD, melalui modul yang akan dihasilkan diharapkan mampu mencegah tindak kekerasan dan penyimpangan seksual khususnya terhadap anak-anak, menambah referensi guru dan orang tua tentang pentingnya pendidikan, serta dijadikan bahan pertimbangan atau rekomendasi bagi pemerintah dalam merancang pendidikan seks yang diintegrasikan ke dalam kurikulum pembelajaran $\mathrm{MI} / \mathrm{SD}$.

\section{METODE}

Metode yang digunakan dalam penulisan artikel ini yakni sebuah pencarian literatur baik internasional maupun nasional yang dilakukan dengan menggunakan jurna- jurnal terkait serta artikel artikel yang berkaitan dengan penelitian ini. Metode analisis yang digunakan adalah analisis deskriptif kualitatif. Dengan analisis deskriptif diharapkan dapat memperoleh data yang komprehensif dan 
mendalam. Langkah-langkah yang dilakukan diantaranya pengumpulan data pustaka, membaca dan mencatat, serta membandingkan literatur untuk kemudian diolah dan menghasilkan kesimpulan. Data yang digunakan merupakan data sekunder yang berasal dari textbook, jurnal, artikel ilmiah, literature review yang berisikan tentang konsep yang diteliti.

\section{HASIL DAN PEMBAHASAN}

\section{Pendidikan Seksual bagi siswa MI/SD \\ Pengertian Pendidikan Seks}

Pendidikan seks merupakan upaya untuk memberikan pengetahuan tentang fungsi organ reproduksi dengan menanamkan moral, etika, serta komitmen agama agar tidak terjadi "penyalahgunaan" organ reproduksi tersebut. Pengertian seksual secara umum adalah sesuatu yang berkaitan dengan alat kelamin atau hal-hal yang berhubungan dengan perkara - perkara hubungan intim antara laki-laki dengan perempuan. Menurut kamus, kata "pendidikan" berarti "proses pengubahan sikap dan tata laku kelompok orang dalam usaha mendewasakan manusia melalui upaya pengajaran dan latihan Sedangkan kata seks mempunya dua pengertian. Pertama, berati jenis kelamin dan yang ke dua adalah hal ihwal yang berhubungan dengan alat kelamin, misalnya persetubuhan atau sanggama. Padahal yang disebut pendidikan seks sebenarnya mempunyai pengertian yang jauh lebih luas, yaitu upaya memberikan pengetahuan tentang perubahan biologis, psikologis, dan psikososial sebagai akibat pertumbuhan dan perkembangan manusia.

Pada umumnya orang menganggap bahwa pendidikan seks hanya berisi tentang pemberian informasi alat kelamin dan berbagai macam posisi dalam berhubungan kelamin. Hal ini tentunya akan membuat para orangtua merasa khawatir. Untuk itu perlu diluruskan kembali pengertian tentang pendidikan seks. pendidikan seks berusaha menempatkan seks pada perspektif yang tepat dan mengubah anggapan negatif tentang seks. Dengan pendidikan seks kita dapat memberitahu anak-anak usia MI/SD bahwa seks adalah sesuatu yang alamiah dan wajar terjadi pada semua orang, selain itu juga dapat diberitahu mengenai berbagai perilaku seksual berisiko sehingga mereka dapat menghindarinya.

Pendidikan seks merupakan upaya transfer pengetahuan dan nilai (knowledge and values) tentangfisik-genetik dan fungsinya khususnya yang terkait dengan jenis (sex) laki-laki dan perempuan sebagai kelanjutan dari kecenderungan primitif makhluk hewan dan manusia yang tertarik dan mencintai lain jenisnya. Pendidikan seks adalah upaya pengajaran, penyadaran, dan penerangan tentang masalah- masalah seksual yang diberikan pada anak, dalam usaha menjaga anak terbebas dari kebiasaan yang tidak Islami serta menutup segala kemungkinan ke arah hubungan seksual terlarang. Pengarahan dan pemahaman yang sehat tentang seks dari aspek kesehatan fisik, psikis, dan spiritual.

Tujuan Pendidikan Seks

Menurut Halstead (Roqib, 2008) secara garis besar pendidikan seks yang diberikan sejak dini memiliki tujuan sebagai berikut: 1) Membantu anak mengetahui topik-topik biologis seperti pertumbuhan, masa puber, dan kehamilan; 2) Mencegah anak-anak dari tindak kekerasan; 3) Mengurang rasa bersalah, rasa malu; 4) kecemasan akibat tindakan seksual; 5) Mencegah remaja perempuan dibawah umur dari kehamilan; 6) Mendorong hubungan yang baik; 7) Mencegah remaja di bawah umur terlibat dalam hubungan seksual (sexual intercourse); 8) Mengurangi kasus infeksi melalui seks; dan 9) Membantu anak muda yang bertanya tentang peran laki-laki dan perempuan di masyarakat. Sehingga dapat disimpulkan secara garis besar adapun tujuan pendidikan seks bagi bagi anak usia MI/SD adalah: 1) Pendidikan seks pada anak MI/SD bertujuan untuk mengenalkan anggota-anggota tubuhnya, sehingga anak mampu merawat dan menjaga anggota tubuhnya dengan baik; 2) Pendidikan seks pada anak $\mathrm{MI} / \mathrm{SD}$ bertujuan untuk merubah pola piker orang tua, guru, dan masyarakat tentang pendidikan seks, sehingga mereka mampu memberikan dan mendiskusikan mengenai pendidikan seks kepada anak sesuai tingkat perkembangannya; dan 3) Pendidikan seks pada anak MI/SD bertujuan untuk memberi kesadaran terhadap orang tua, guru, dan masyarakat tentang pentingnya menjaga anak-anak dari perbuatan kekerasan dan pelecehan seksual. 
Teknik Pendidikan Seks Anak Usia MI/SD

Anak adalah organisme yang memiliki keunikannya masing-masing. Namun, terdapat kesamaan diantara anak-anak usia MI/SD, yaitu mereka sering melakukan peniruan. Terkadang sifat peniruan ini tidak disadari oleh kebanyakan orang tua dan guru, terutama mengenai seks. Secara edukatif, anak bisa diberi pendidikan seks sejak ia bertanya di seputar seks. Bisa jadi pertanyaan anak tidak terucap lewat kata-kata, untuk itu ekspresi anak harus bisa ditangkap oleh orangtua atau pendidik. Nurhayati Syaifuddin(Roqib, 2008) menyatakan bahwa pendidikan seks untuk anak usia MI/SD tahun adalah dengan teknik atau strategi sebagai berikut: 1) Membantu anak agar ia merasa nyaman dengan tubuhnya; 2) Memberikan sentuhan dan pelukan kepada anak agar mereka merasakan kasih saying dari orang tuanya secara tulus; 3) Membantu anak memahami perbedaan perilaku yang boleh dan yang tidak boleh dilakukan di depan umum seperti anak selesai mandi harus mengenakan baju kembali di dalam kamar mandi atau di dalam kamar. Anak diberi tahu tentang hal-hal pribadi, tidak boleh disentuh, dan dilihat orang lain; 4) Mengajar anak untuk mengetahui perbedaan anatomi tubuh lakilaki dan perempuan; 5) Memberikan penjelasa tentang proses perkembangan tubuh seperti hamil dan melahirkan dalam kalimat yang sederhana, bagaimana bayi bisa dalam kandungan ibu sesuai tingkat kognitif anak. Tidak diperkenankan berbohong kepada anak seperti "adik datang dari langit ataudibawa burung". Penjelasan disesuaikan dengan keingintahuan atau pertanyaan anak misalnya dengan contoh yang terjadi pada binatang; 6) Memberikan pemahaman tentang fungsi anggota tubuh secara wajar yang mampu menghindarkan diri dari perasaan malu dan bersalah atas bentuk serta fungsi tubuhnya sendiri; 7) Mengajarkan anak untuk mengetahui nama-nama yang benar pada setiap bagian tubuh dan fungsinya. Vagina adalah nama alat kelamin perempuan dan penis adalah alat kelamin pria, dari pada mengatakan dompet atau burung; 8) Membantu anak memahami konsep pribadi dan mengajarkan kepada mereka kalau pembicaraan seks adalah pribadi; 9) Memberi dukungan dan suasana kondusif agar anak mau berkonsultasi kepada orangtua untuk setiap pertanyaan tentang seks; 10) Perlu ditambahkan, teknik pendidikan seks dengan memberikan pemahaman kepada anak tentang susunan keluarga (nasab) sehingga memahami struktur sosial dan ajaran agamayang terkait dengan pergaulan lakilaki dan perempuan; 11) Membiasakan dengan pakaian yang sesuai dengan jenis kelaminnya dalam kehidupan sehari- hari dan juga saat melaksanakan salat akan mempermudah anak memahami dan menghormati anggota tubuhnya; 12) Sebagaimana telah disebutkan, teknik pendidikan seks tersebut dilakukan dengan menyesuaikan terhadap perkembangan anak sehingga teknik penyampaian dan bahasa amat perlu dipertimbangkan; dan 13) Sebagaimana telah disebutkan, teknik pendidikan seks tersebut dilakukan dengan menyesuaikan terhadap perkembangan anak sehingga teknik penyampaian dan bahasa amat perlu dipertimbangkan.

\section{Pendidikan Seksual dalam Islam}

Pendidikan seks menjadi bagian dari aspek dalam pandangan Al-Qur'an. Mendidik masyarakat dalam memahami pendidikan seksual yang selaras dengan tuntunan Al-Qur'an untuk mematuhi perintah dan larangan Allah SWT terhadap manusia dengan kata lain sebagai satu ibadah. konsep pendidikan seks yang telah banyak dijelaskan dalam Al-Qur'an harus dilihat secara menyeluruh dan akan mendapatkan suatu konsep dalam mendidik anak bangsa tentang seksualitas sehingga akan berimplikasi pada kehidupan yang harmonis, sejahtera, dan juga membuang kesalahpemahaman terhadap pendidikan seks agar dalam kehidupan bermasyarakat dapat mencapai yang diharapkan. (Muhammad Taufik, 2010). Pendidkan seksual islami mengandung dua aspek, yang salah satunya berperan dalam menyiapkan dan membekali anak mumayyiz dengan pengetahuan-pengetahuan teoritis tentang masalah-masalah seksual. Perhatian dan perlindungan syariat Islam terhadap anak ditandai dengan kekomprehensifannya dalam menyentuh seluruh aspek pertumbuhan dan perkembangan anak. Islam memperhatikan bimbingan seksual bagi berbagai kelompok umur. Mengingat hal itu merupakan bagian program dari pendidikan yangtak terpisahkan, maka permulaan bimbingan berbeda antara satu fase dengan fase yang lain dengan konsep dan metode yang sesuai dengan karakteristik setiap fase tumbuh kembangnya anak. Pendidikan seks yang diberikan pun harus berdasarkan atau 
sesuai dengan prinsip Al-Quran dan sunnah. Al-Quran merupakan pedoman bagi seluruh aspek kehidupan, baik aspek sosial, budaya, politik, hukum dan pendidikan.

Dalam hal ini pendidikan seks menjadi bagian dari aspek dalam pandangan Al-Quran. Termasuk mendidik anak dalam memahami pendidikan seksual yang sesuai dengan kaidah dalam Al-Quran adalah bagian dari mematuhi perintah dan larangan Allah SWT terhadap manusia dengan kata lain sebagai satu ibadah. Allah SWT berfirman:

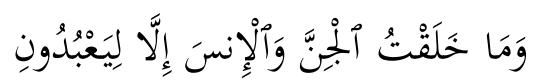

"Tidaklah Kuciptakan jin dan manusia kecuali supaya mereka beribadah kepada-Ku."

(QS. Az-Zariyat: 56)

Pendidikan seks di dalam Islam merupakan bagian yang tidak dapat terpisahkan dari pendidikan akidah, akhlak, dan ibadah. Terlepasnya pendidikan seks dengan ketiga unsur itu mungkin dapat menyebabkan ketidakjelasan arah dari pendidikan seks itu sendiri, bahkan mungkin akan menimbulkan kesesatan dan penyimpangan dari tujuan asalnya. Oleh karena itu, pelaksanaan pendidikan seks tidak boleh menyimpang dari tuntutan syariat Islam. Pendidikan seksual memerlukan perhatian karena merupakan satu mekanisme untuk memahami serta memelihara pribadi itu sendiri (generasi muda) dari sejak dini hingga dewasa kelak, hal ini tertera dalam Al-Quran. Firman Allah SWT:

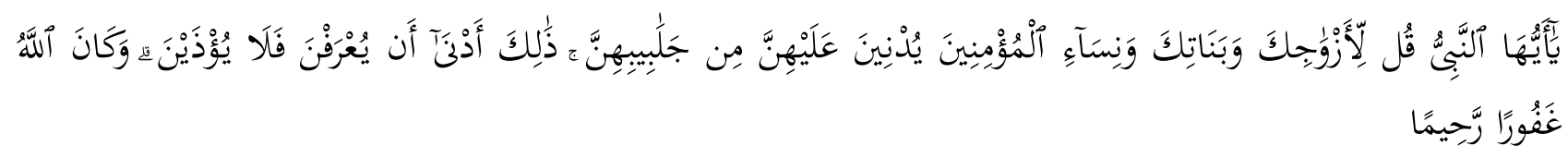

"Hai Nabi, katakanlah kepada isteri-isterimu, anak-anak perempuanmu dan isteri-isteri orang mukmin: "Hendaklah mereka mengulurkan jilbabnya ke seluruh tubuh mereka". Yang demikian itu supaya mereka lebih mudah untuk dikenal, karena itu mereka tidak di ganggu. Dan Allah adalah Maha Pengampun lagi Maha Penyayang. (Al-Ahzab:59)

Konsep pendidikan seks islami bagi anak-anak dalam islam adalah utamanya memprioritaskan pendidikan tentang Tauhid, terutama tentang keberadaan Allah yang selalu mengawasi kita dimana saja dan kapan saja. Pendidikan seks islam juga berhubungan dengan pendidikan tentang keluarga dan dimana yang perlu ditekankan adalah bahwa perilaku seks yang menyimpang dan melanggar syariat Allah SWT akan menerima hukuman baik didunia (mendapat keturunan yang sulit untuk dididik, kecaman dari berbagai pihak, dan kesulitan lain karena belum memiliki ilmu) apalagi diakhirat kelak. Ajaran islam menuntun moral luhur anak sejak usia dini, mengajarkan kepada mereka etika kesantunan dan penghormatan kepada orang tua, menjaga penglihatan, dari hal-hal buruk yang tidak sesuai dengan nilai-nilai syariat. Semua itu merupakan pondasi yang kokoh untuk membentengi perilaku dan moral anak, supaya kelak ketika menginjak usia puber, mereka tetap pada koridor kebenaran serta pada jalur syariat. Bahkan, lebih daripada itu tuntunan moral seperti itu merupakan langkah bijak agar nantinya anak-anak ketika dewasa tidak rapuh menghadapi godaan hidup yang dapat meruntuhkan sendi-sendi moralitas, atau persisnya yang akan mengantarkan kedalam perzinaan, sebagaimana kita ketahui bahwa ternyata memori anak lebih kuat dibandingkan dengan orang dewasa. Sehingga pendidikan, bimbingan dan penjagaan orang tua atau para pendidik bagi anak bukan hanya sekedar mengajarkan saja akan tetapi mampu dan siap menjadi role mode yang baik untuk dicontoh dan ditiru, Rasulullah SAW bersabda: "Barang siapa memberi suritauladan didalam islam dengan suri tauladan yang baik, maka baginya memperoleh pahalanya dan pahala orang yang mengerjakannya dengan tanpa mengurangi sedikitpun dari pahala mereka. Dan barang siapa memberi suri tauladan didalam islam dengan suri-tauladan yang buruk, maka ada baginya memperoleh dosanya dan dosa orang yg mengerjakannya dengan tanpa mengurangi sedikitpun dari dosa-dosa mereka." (HR. Muslim \& Nasai). (Nurul aini, 2017). 


\section{Implikasi Pendidikan Seksual dalam Pembelajaran \\ Pendidikan Seksual dalam Pembelajaran}

Berkaitan dengan bagaimana seharusnya sekolah berperan aktif terhadap pendidikan seksual, yang terutama dan terpenting adalah sekolah (para guru) harus memiliki paradigma yang persis terbalik dengan pandangan negative terhadap pendidikan seks oleh masyarakat pada umumnya. Bahwa pendidikan seks itu penting dan perlu diberikan sedini mungkin. Paradigma ini lah yang seharusnya dimiliki oleh sekolah. Menurut pendapat penulis, pendidikan seksual yang menekankan pada aspek biologis, psikologis, sosial, dan kultural dapat diberikan dalam pelayanan bimbingan. Pada hakekatnya, bimbingan adalah "the process of helping individuals to understand themselves and their world (Sherzer \& Stone, 1976, 1981 dalam Winkel \& Sri Hastuti, 2012). Menurut Natawijaya (1981 dalam Winkel \& Sri Hastuti, 2012) bimbingan adalah pemberian bantuan kepada individu yang dilakukan secara berkesinambungan supaya individu tersebut dapat memahami dirinya sehingga ia sanggup mengarahkan diri dan dapat bertindak wajar sesuai dengan tuntuan dan keadaan keluarga serta masyarakat. Dengan demikian dia dapat mengecap kebahagiaan hidupnya serta dapat memberikan sumbangan yang berarti. "Memahami dirinya, memahami dunianya" dapat dimaknai bahwa individu tidak terbatas memahami jenis kelamin (seks) tetapi lebih luas dari itu. "Memahami diri" artinya memahami diri sebagai mahluk seksual yang memiliki aspek-aspek biologis, psikologis, sosial, dan kultural. Misalnya, memahami identitas gender, peran gender, orientasi seks, bagaimana individu mengalami perasaan-perasaan, bagaimana individu berelasi dengan individu lain, adalah contoh-contoh memahami diri sebagai mahluk seksual.

Menurut Winkel dan Sri Hastuti (2012), terdapat tiga pandangan dasar pelayanan bimbingan di $\mathrm{MI} / \mathrm{SD}$ yaitu bimbingan terbatas pada pengajaran yang baik, bimbingan hanya diberikan kepada siswa yang menunjukkan gejala penyimpangan, dan pelayanan bimbingan yang tersedia untuk semua siswa. Pada keadaan dewasa ini dimana kematangan seksual semakin dan masa puber semakin cepat datangnya, pandangan pelayanan bimbingan untuk semua siswa diakui sebagai pandangan yang paling tepat. Untuk tingkat MI/SD sebetulnya telah diperlukan tenaga bimbingan profesional untuk menangani masalah-masalah khusus, namun demikian peran guru kelas tetap diperlukan. Guruguru kelas dapat menyisipkan materi pendidikan seksual dalam materi pelajaran yang relevan. Pelayanan bimbingan berdasarkan pada: 1) Kebutuhan anak sekolah yang terutama berkisar pada kebutuhan mendapatkan kasih sayang dan perhatian, menerima pengakuan terhadap dorongan untuk memajukan perkembangan kognitifnya,serta memperoleh pengakuan dari teman sebaya; 2) Tugas perkembangan anak sekolah antara lain belajar bergaul dan bekerja dengan kelompok sebaya, belajar memahami diri sendiri dan orang lain sesuai dengan jenis kelaminnya dan menjalankan peran tanpa membedakan jenis kelamin, membina hidup sehat untuk diri sendiri dan lingkungan (Pusat Kurikulum Depdiknas, 2003); 3) Bentuk bimbingan yang terutama digunakan adalah bimbingan kelompok; 4) Sifat bimbingan yang mencolok adalah persevertif dan preventif; 5) Layanan konsultasi guru dengan orangtua sangat diprioritaskan. Konseling dipegang oleh ahli bimbingan professional; dan 6) Materi bimbingan, dalam hal ini materi pendidikan seksual, selain terintegrasi dengan mata pelajaran yang relevan, dapat pula diberikan secara terpisah melalui pertemuan khusus pelayanan bimbingan.

Dari sudut pandang tugas perkembangan atau aspek perkembangan, pendidikan seksual adalah suatu usaha untuk membantu siswa memenuhi tugas perkembangan seturut dengan norma dan tuntutan lingkungan (aspek kultur). Menurut pendapat penulis, untuk siswa MI/SD, aspek perkembangan yang langsung berkaitan dengan seksualitas adalah pengembangan pribadi (dimensi psikologis), kesadaran gender (dimensi psikologis), kematangan hubungan dengan teman sebaya (dimensi sosial). Berikut dibawah ini standar kompetensi kemandirian siswa yang dapat dijadikan tujuan pendidikan seksual. 
134 Instructional Development Journal (IDJ), Vol. 3, No. 2, Agustus 2020, Hal. 128-138

Tabel 1. Standar Kompetensi Kemandirian Siswa MI/SD untuk Pendidikan Seksual

\begin{tabular}{|c|c|c|c|c|}
\hline No & $\begin{array}{c}\text { Internalisasi } \\
\text { Tujuan }\end{array}$ & Pengembangan Diri & Kesadaran Gender & $\begin{array}{c}\text { Kematangan hubungan } \\
\text { dengan teman sebaya }\end{array}$ \\
\hline 1. & Pengenalan & $\begin{array}{l}\text { Mengenal keberadaan } \\
\text { diri dalam lingkungan } \\
\text { dekatnya. }\end{array}$ & $\begin{array}{l}\text { Mengenal diri sebagai } \\
\text { laki- laki atau } \\
\text { perempuan }\end{array}$ & $\begin{array}{lr}\text { Mengenal } & \text { norma-norma } \\
\text { dalam } & \text { berinteraksi } \\
\text { dengan teman sebaya. }\end{array}$ \\
\hline 2. & $\mathrm{Akc}$ & $\begin{array}{l}\text { Menerima keadaan } \\
\text { diri sebagai bagian } \\
\text { dari lingkungan }\end{array}$ & $\begin{array}{lr}\text { Menerima } & \text { atau } \\
\text { menghargai } & \text { diri } \\
\text { sebagai laki-laki } & \text { atau } \\
\text { perempuan } & \end{array}$ & $\begin{array}{lr}\text { Menghargai } & \text { norma- } \\
\text { norma yang dijunjung } \\
\text { tinggi dalam menjalin } \\
\text { persahabatan } \\
\text { teman sebaya. }\end{array}$ \\
\hline 3. & Tindakan & $\begin{array}{l}\text { Menampilkan } \\
\text { perilaku sesuai dengan } \\
\text { keberadaan diri dalam } \\
\text { lingkungannya, }\end{array}$ & $\begin{array}{lr}\text { Berperilaku } & \text { sesuai } \\
\text { dengan peran } & \text { sebagai } \\
\text { laki-laki } & \text { atau } \\
\text { perempuan. } & \end{array}$ & $\begin{array}{l}\text { Menjalin persahabatan } \\
\text { dengan teman sebaya atas } \\
\text { dasar norma yang } \\
\text { dijunjung tinggi bersama. }\end{array}$ \\
\hline
\end{tabular}

Dengan memperhatikan isi tugas-tugas perkembangan dan semakin cepatnya masa puber di usia sekolah $\mathrm{MI} / \mathrm{SD}$, maka penulis mengusulkan materi-materi pendidikan seksual yang diperlukan oleh siswa MI/SD (lebih tepat untuk usia 10-12 tahun) sebagai berikut di bawah ini:

Tabel 2. Usulan Materi-materi Pendidikan Seksual Untuk Siswa MI/SD

\begin{tabular}{|c|c|c|c|c|}
\hline No & Dimensi Biologis & $\begin{array}{l}\text { Dimensi } \\
\text { Psikologis }\end{array}$ & Dimensi Sosial & Dimensi Kultural \\
\hline 1. & $\begin{array}{l}\text { Ciri-ciri seksualitas } \\
\text { primerdan } \\
\text { sekunder }\end{array}$ & $\begin{array}{l}\text { Perbedaan Antar laki-laki } \\
\text { dan perempuan }\end{array}$ & $\begin{array}{l}\text { Berperilaku sesuai } \\
\text { dengan peran } \\
\text { sebagai laki-laki } \\
\text { atau perempuan }\end{array}$ & $\begin{array}{lr}\text { Pengenalan norma- } \\
\text { norma } & \text { dalam } \\
\text { berinteraksi dengan } \\
\text { teman sebaya }\end{array}$ \\
\hline 2. & $\begin{array}{l}\text { Pengenalan bagian } \\
\text { tubuh, } \\
\text { organ, dan } \\
\text { fungsinya. }\end{array}$ & $\begin{array}{l}\text { Pengenalan diri sebagai laki- } \\
\text { laki atau perempuan }\end{array}$ & $\begin{array}{lr}\text { Pergaulan } & \text { sehat } \\
\text { dengan teman } & \text { tema antara laki- } \\
\text { sebaya } & \text { daki } \\
\text { perempuan } & \end{array}$ & $\begin{array}{l}\text { Penghargaan norma- } \\
\text { norma yang berlaku } \\
\text { dimasyarakat dan } \\
\text { menjunjung tinggi } \\
\text { norma-norma itu }\end{array}$ \\
\hline 3. & $\begin{array}{l}\text { Persiapan } \\
\text { memasuki } \\
\text { masa } \\
\text { menarcher } \\
\text { spermache }\end{array}$ & $\begin{array}{l}\text { Menampilkan Penghargaan } \\
\text { diri sebagai laki- laki atau } \\
\text { perempuan }\end{array}$ & 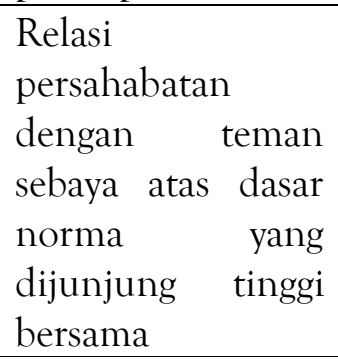 & - \\
\hline
\end{tabular}

Materi Pendidikan Seksual yang diberikan di MI/SD Terutama kelas 5-6

Ada beberapa materi yang disajikan dalam Pendidikan seksual di kelas 5-6 tingkat MI/SD antara lain sebagai berikut: 1) Keterbukaan pada orang tua; 2) Pengarahan akan persepsi mereka tentang seks bahwa hal tersebut mengacu pada jenis kelamin dan bukan lagi tentang hal-hal diluar itu (hubungan laki-laki dan perempuan, proses membuat anak dst); 3) Perbedaan antara laki-laki dan perempuan; 4) Pengenalan bagian tubuh organ dan fungsinya; 5) Memakai bahasa yang baik dan benar tentang seks menggunakan bahasa ilmiah, seperti 'Penis', 'Vagina; 6) Pengenalan system organ seks secara sederhana; 7) Anatomi system reproduksi secara sederhana; 8) Cara merawat kesehatan dan kebersihan organ tubuh termasuk organ reproduksi; 9) Mengajarkan anak untuk menghargai dan melindungi tubuhnya sendiri; 10) Proses kehamilan dan persalinan sederhana; 11) Mempersiapkan anak untuk memasuki masa pubertas; 12) Perkembangan fisik dan psikologis yang terjadi pada remaja; 13) Ciri 
seksualitas primer dan sekunder; 14) Proses terjadinya mimpi basah; 15) Proses terjadinya ovulasi dan menstruasi secara sederhana; dan 16) Memberikan pemahaman pada para siswa mengenai pendidikan seksual agar siswa dapat memiliki sikap positif dan perilaku yang bertanggung jawab terhadap kesehatan reproduksi secara umum.

\section{Peran Orang tua dalam Pendidikan Seks Anak MI/SD}

Ketika orang tua anak menghadapi masalah dan tidak tahu harus bagaimana membuka mulut untuk memulai pembicaraan, sering kali mereka mengambil tindakan yang pasif, atau mengira diserahkan kepada guru di sekolah untuk mengajar mereka dengan lebih layak. Sebenarnya nilai pandang dan sikap orang tua itu sendiri terhadap seks merupakan siklus belajar bagi anak - anak mereka. Jika menerima penyampaian seks yang menyimpang (dari media) atau menerima informasi tentang seks yang salah, ayah dan ibu mempunyai kewajiban untuk segera memberikan bimbingan yang tepat dan mengklarifikasi permasalahan, juga harus mencegah agar informasi dari media yang tidak sehat tidak menyerang masuk ke dalam keluarga. Sebenarnya keluarga merupakan siklus yang paling penting dalam melaksanakan pendidikan seks. Di bawah ini adalah beberapa prinsip penting di dalam pendidikan seks keluarga, kami berikan kepada para orang tua sebagai bahan referensi: 1) Siap Memberikan Pendidikan Seks setiap saat; 2) Memberi Teladan dan Bimbingan Lisan Secara Bersamaan; 3) Menerima pertanyaan dan memberi jawaban yang tepat; dan 4) Penekanan untuk menghormati dan privasi.

\section{Penyimpangan Seksual Pada Anak (LGBT dan Kekerasan Seksual)}

Lesbian, Gay, Biseksual, dan Transgender (LGBT)

LGBT adalah kelompok yang memiliki orientasi seksual yang berbeda dengan heteroseksual. Lesbian adalah istilah bagi perempuan yang mengarahkan orientasi seksualnya kepada perempuan atau perempuan yang mencintai perempuan, baik secara fisik, seksual, emosional atau secara spiritual. Gay adalah istilah untuk laki-laki yang mengarahkan orientasi seksualnya kepada sesama laki-laki atau lakilaki yang mencintai laki-laki, baik secara fisik, seksual, emosional atau secara spiritual. Biseksual adalah orientasi seks yang mempunyai ciri-ciri berupa ketertarikan estetis, cinta romantik dan hasrat seksual kepada pria dan wanita. Transgender adalah istilah yang digunakan untuk mendeskripsikan orang yang melakukan, merasa, berfikir atau melihat berbeda dari jenis kelamin yang ditetapkan saat lahir. Penyebab seseorang menjadi LGBT itu sangat kompleks. Berdasarkan hasil penelitian USAID (2014) menunjukkan bahwa faktor penyebab seseorang menjadi LGBT antara lain faktor sosial dan faktor biologis, akan tetapi lebih banyak yang menjadi penyebabnya adalah faktor sosial. Keluarga juga memiliki peran penting dalam membentuk seseorang menjadi LGBT. Orang tua yang bercerai biasanya bisa membuat anak kehilangankasih. saying dari salah satu orang tuanya. Hal ini membuat anak mencari sosok yang hilang tersebut dalam dirinya. Pola asuh yang salah juga bisa menjuruskan anak untuk menjadi LGBT. Orang tua yang terlalu sibuk bekerja sehingga kurang memperhatikananak. Orang tua yang terlalu membebaskan anak dan tidak memberikan pengajaran agama yang cukup juga bisa membuat anak menjadi LGBT.

Upaya pencegahan LGBT dalam kehidupan yang mulai remaja khususnya tingkat MI/SD melalui konsep LGBT dalam perspektif Islam harus dicoba untuk membantu para orang tua dan pendidik mengontrol perilaku anak dan remaja MI/SD yang memasuki masa pubertas agar mereka tidak menyetujui dan sepakat menghindarkan diri dari orientasi seksual yang menyimpang (LGBT). Pembahasan dan penelitian tentang konsep LGBT dalam Islam peneliti batasi dengan masalah seputar pemahaman konsep LGBT oleh guru, orang tua, dan murid. Terutama murid MI/SD yang sudah mengalami masa baligh yang sedang memasuki masa pubertas atau remaja awal sedang mengalami perubahan biologis (hormonal) dan psikis yang signifikan sehingga sehingga perlu dilindungi dan dihindarkan dari LGBT. Upaya tersebut dapat dilakukan dengan melalui training guru-guru agama dengan menggunakan modul bagi guru untuk yang dapat diujicobakan dalam pelajaran di kelas. Sedangkan untuk muridnya akan dibuatkan buku saku tentang penilaian sikap dan sebagainya. Tujuannya adalah guru dan murid mengerti dan memahami tentang LGBT, dan selanjutnya menghindari serta menjauhinya. Hal tersebut sebagai upaya penyadaran akan bahaya perilaku LGBT 
pada anak-anak dan remaja berikut pandangan Islam dan strategi penanganannya agar selamat dan terhindar dari perilaku LGBT. (Ermayani, 2017).

\section{Kekerasan Seksual}

Kekerasan seksual adalah kekerasan yang dapat menyebabkan luka secara fisik maupun psikis kepada anak. Hal ini akan menjadi momok yang menakutkan bagi anak karena akan berbekas sebagai ingatan buruk. Kekerasan seksual yang terjadi pada anak lakilaki ataupun perempuan adalah orang dewasa yang dekat dan dihormati oleh anak. Pelaku kekerasan seksual kepada anak dalam dua kategori yaitu, yang dilakukan oleh keluarga atau orang yang dipercaya dalam menjaga anak tersebut (familial abuse) dan yang dilakukan oleh orang yang memiliki relasi kedekatan dengan korban (extra familial abuse) (Noviana, 2015). Faktor penyebab kekerasan seksual dalam penelitiannya bisa dikarenakan kelalaian orang tua, rendahnya mentalitas dan moralitas pelaku, dan bisa dikarenakan factor ekonomi.Terdapat perbedaan yang mencolok antara anak yang telah mendapatkan pendidikan seks dasar dan yang tidak. Ketika seseorang meminta anak yang telah mendapatkan pendidikan seks dasar diminta menunjukkan kelaminnya, anak tersebut menolak. Dan anak yang tidak mendapatkan pendidikan dasar ketika diminta menunjukkan kelaminnya, anak tersebut mau menunjukkan.

Dampak psikologis yang dialami oleh korban kekerasan seksual digolongkan tiga perilaku, yaitu: 1) Gangguan perilaku seperti tidak ingin melakukan sesuatu dan cenderung untuk berdiam diri; 2) Gangguan kognisi yaitu keadaan dimana korban mengalami gangguan pada belajar sehingga nilai akademik korban ataupun kegiatan belajar korban menurun; dan 3) Gangguan emosional yaitu dimana korban cenderung memiliki suasana hati yang sering berubah-ubah dan menyalahkan diri sendiri. Kekerasan seksual menimbulkan dampak traumatis dan kepada korban, terlebih jika terjadi pada anakanak. Hal ini dikarenakan anak-anak belum memahami bahwa dirinya telah menjadi korban kekerasan seksual. Anak-anak yang menerima ancaman saat terjadi kekerasan seksual menjadi ketakutan untuk melaporkan hal tersebut kepada orang tua atau orang dewasa terdekat. Jika masalah kekerasan seksual pada dibiarkan, maka banyak generasi bangsa kita yang mengalami pertumbuhan yang tidak maksimal. Anak-anak memiliki memori yang dapat mereka ingat sampai nanti mereka dewasa. Ketika mengalami sesuatu yang tindakan yang buruk, maka anak akan mengingatnya menjadi ingatan yang terbawa hingga dewasa. Oleh karena itu, anak sangat perlu mendapatkan perlindungan dari khususnya kekerasan seksual. (Peni W. A, 2018).

\section{SIMPULAN DAN SARAN Simpulan}

Pendidikan seks merupakan upaya transfer pengetahuan dan nilai (knowledge and values) tentang fisik-genetik dan fungsinya khususnya yang terkait dengan jenis (sex) laki-laki dan perempuan sebagai kelanjutan dari kecenderungan primitif makhluk hewan dan manusia yang tertarik dan mencintai lain jenisnya. Pendidkan seksual islami mengandung dua aspek, yang salah satunya berperan dalam menyiapkan dan membekali anak mumayyiz dengan pengetahuan-pengetahuan teoritis tentang masalah-masalah seksual. Perhatian dan perlindungan syariat Islam terhadap anak ditandai dengan kekomprehensifannya dalam menyentuh seluruh aspek pertumbuhan dan perkembangan anak. Islam memperhatikan bimbingan seksual bagi berbagai kelompok umur. Mengingat hal itu merupakan bagian program dari pendidikan yangtak terpisahkan, maka permulaan bimbingan berbeda antara satu fase dengan fase yang lain dengan konsep dan metode yang sesuai dengan karakteristik setiap fase tumbuh kembangnya anak. Pendidikan seks yang diberikan pun harus berdasarkan atau sesuai dengan prinsip al-Quran dan sunnah. al-Quran merupakan pedoman bagi seluruh aspek kehidupan, baik aspek sosial, budaya, politik, hukum dan pendidikan.

Terdapat tiga pandangan dasar pelayanan bimbingan di MI/SD yaitu bimbingan terbatas pada pengajaran yang baik, bimbingan hanya diberikan kepada siswa yang menunjukkan gejala penyimpangan, dan pelayanan bimbingan yang tersedia untuk semua siswa. Pada keadaan dewasa ini dimana kematangan seksual semakin dan masa puber semakin cepat datangnya, pandangan pelayanan bimbingan untuk semua siswa diakui sebagai pandangan yang paling tepat. Dari sudut pandang tugas 
perkembangan atau aspek perkembangan, pendidikan seksual adalah suatu usaha untuk membantu siswa memenuhi tugas perkembangan seturut dengan norma dan tuntutan lingkungan (aspek kultur). Menurut pendapat penulis, untuk siswa MI/SD, aspek perkembangan yang langsung berkaitan dengan seksualitas adalah pengembangan pribadi (dimensi psikologis), kesadaran gender (dimensi psikologis), kematangan hubungan dengan teman sebaya (dimensi sosial).

Lesbian, Gay, Biseksual, dan Transgender (LGBT) adalah kelompok yang memiliki orientasi seksual yang berbeda dengan heteroseksual. Lesbian adalah istilah bagi perempuan yang mengarahkan orientasi seksualnya kepada perempuan atau perempuan yang mencintai perempuan, baik secara fisik, seksual, emosional atau secara spiritual. Gay adalah istilah untuk laki-laki yang mengarahkan orientasi seksualnya kepada sesama laki-laki atau laki-laki yang mencintai laki-laki, baik secara fisik, seksual, emosional atau secara spiritual. Biseksual adalah orientasi seks yang mempunyai ciri-ciri berupa ketertarikan estetis, cinta romantik dan hasrat seksual kepada pria dan wanita. Transgender adalah istilah yang digunakan untuk mendeskripsikan orang yang melakukan, merasa, berfikir atau melihat berbeda dari jenis kelamin yang ditetapkan saat lahir

\section{Saran}

Berdasarkan kesimpulan yang telah diungkapkan, maka saran yang dapat disampaikan adalah agar para orang tua dan Guru dapat memberikan perhatian dan pengawasan yang cukup bagi anak saat dirumah serta memberikan teladan yang baik untuk anak. Sedangkan bagi para guru agar dapat memberikan perhatian dan pengawasan di sela-sela kesibukan yang dilakukannya.

\section{DAFTAR RUJUKAN}

Awaludin, L. (2008). Cerdas Seksual "Sex Education for Teenagers". Bandung: Shofie Media.

Budiningsih, A. (2004). Belajar dan pembelajaran. Jakarta: Rineka Cipta. Dahar, R.E. (2011). Teori-Teori Belajar dan Pembelajaran. Jakarta: Erlangga.

Ilahi, F. (2014). Bersama Rasulullah Mendidik Generasi Idaman. Jakarta: Pustaka Imam Asy-Syafi'i.

Lestari, E., et al. (2014). Peran Orang Tua Dalam Memberikan Pendidikan Seks Sedini Mungkin di TK Mardisiswi Desa Kedondong Kecamatan Kebonsari KabupatenM adiun. Jurnal Ilmiah Pendidikan, $02(02)$.

Thomas, L. (2012). Pendidikan Karakter. Kreasi Wacana Bantul.

Mahasiswa S2 Prodi Paud Kelas D. (2013). Kekerasan Seksual Terhadap Anak Usia Dini.

Taufik, M. (2010). https://naifu.wordpress.com/2010/08/12/pendidikan-seks-menurut-perspektif-alqur\%E2\%80\%99an/.

Noviana, I. (2015). Kekerasan Seksual terhadap Anak: Dampak dan Penanganannya. Jakarta: Pusat Penelitian dan Pengembangan Kesejahteraan Sosial. Kementerian Sosial Republik.

Aini, N. (2017). Urgensi Pendidikan Seksual yang Islami untuk Anak PROSIDING Rapat Kerja Fakultas Ilmu Kesehatan, Prosiding: Peningkatan Keilmuan Solusi Tantangan Profesi Kesehatan, hal 51. 59.

Agustina, P., W. (2018). Analisis Tindak Kekerasan Seksual Pada Anak Sekolah Dasar. Jurnal Kajian Teori dan Praktik Kependidikan. Volume 3, Nomor 2. hal 151-155

Amelia, R. (2019). Upaya Smp Pgri 8 Surabaya dalam Melakukan Pencegahan dan Penanganan Human Trafficking: Kajian Moral dan Kewarganegaraan, Volume 07 Nomor, 3, hal 121-135

Roqib, M. (2008). Pendidikan Seks pada Anak Usia Dini. Jurnal Pemikiran Alternatif Pendidikan, Vo. 13, No. 2, hal 271-286 
138 Instructional Development Journal (IDJ), Vol. 3, No. 2, Agustus 2020, Hal. 128-138

Santrock, J.W. (2007). Perkembangan Anak (Edisi Kesebelas) (Jilid I). (Terjemahan Mila Racmawati E⿱ Anna Kuswati). New York City: McGraw-Hill. (Buku asli diterbitkan tahun 2007).

Sarwono, S. W. (2008). Psikologi Remaja. Jakarta: Rajagrafindo Persada

Slavin, R.E. (2008). Psikologi Pendidikan: Teori dan Praktik (Edisi Kedelapan) (Jilid I). (Terjemahan Marianto Samosir). Upper Saddle River: Pearson. (Buku asli diterbitkan tahun 2006).

Suwaid, M. (2010). Propethic Parenting; Cara Nabi SAW Mendidik Anak. Yogyakarta: Pro-U Media.

Hastuti, S. (2014). Pendidikan Seksual Anak di TK dan SD: Seminar Sanata Dharma, Yogyakarta.

Ermayani, T. (2017). LGBT dalam Perspektif Islam. Jurnal Humanika, Th. XVII, No. 1. hal 81-100.

Willis, S. (2005). Remaja dan Masalahnya, Mengupas Berbagai Bentuk Kenakalan Remaja. Bandung: Alfabeta.

Winkel, W. S \& Sri Hastuti, M. M. (2012). Bimbingan dan Konseling di Institusi Pendidikan. Yogyakarta: Media Abadi.

http://www.kpai.go.id/berita/kpai-pelaku- kekerasan-terhadap-anak-tiap-tahun- meningkat/, diakses tanggal 13 April 2020 , Pukul 21.45 WIB.

http://nasional.kompas.com/read/2016/05/13/23025921/Mendikbud.Nilai.Kekerasan.Seks ual.pada.Anak.Muncul.karena.Potensi.Masalah.Dibiarkan, diakses tanggal tanggal 13 April 2020, Pukul 22.30 WIB.

http://kesehatanlingkunganmasyarakat.blogspot.com/2011/09/fakta-demam-berdarah-dengue.html. diakses tanggal tanggal 13 April 2020, Pukul 21.20 WIB. 